\title{
THE EFFECT OF DIMETHYL ETHER (D.M.E.) AS LPG SUBSTITUTION ON HOUSEHOLD STOVE: MIXTURE STABILITY, STOVE EFFICIENCY, FUEL CONSUMPTION, AND MATERIALS TESTING
}

\author{
Galuh Wirama Murti ${ }^{1}$, Unggul Priyanto', Imron Masfuri', Nesha Adelia ${ }^{1}$ \\ ${ }^{1}$ Center of Technology for Energy Resources and Chemical Industry \\ Agency for the Assessment and Application of Technology \\ e-mail:galuh.wirama@bppt.go.id
}

\begin{abstract}
DME has characteristics similar to L.P.G. so that the storage and handling are not different from L.P.G. D.M.E. could be used as a solvent that can extract typical types of rubber/polymer material. The aims and objectives of this study are to determine the effect of blending DME/LPG ratios (100/0, 80/20, 50/50, 30/70, $20 / 80$ ) on the stability of the DME/LPG mixture, the efficiency of the stove, and the fuel consumption. The highest efficiency of the stove with blending DME/LPG was $71.29 \%$ and was achieved by the LPG-DME stove with $50 / 50$ DME/LPG. This result shows the stove design has an enormous effect on efficiency. The increasing D.M.E. ratio in the blending fuel can raise fuel consumption. The study also observes the effect of the blending on several stove accessories rubber materials. The study reveals that the usage of a DME/LPG with blend ratios between 20/80 - 30/70 does not require a replacement of any substitute materials but only requires minor modifications to the stove. However, at a higher D.M.E. composition, the use of the fuel needs to replace the seal that is resistant to D.M.E.
\end{abstract}

Keywords: dimethyl ether; LPG; stability; stove; the rubber material Received: 2021-05-03; Revised: 2021-07-19; Accepted: 2021-07-19

\section{INTRODUCTION}

Currently, the demand for L.P.G. for the household and the transportation sector in Indonesia reaches 7.5 million tons, while domestic production is 2 million tons (26\%) and imports of 5.5 million tons (74\%) in 2018 [1]. The demand for L.P.G. will continue to increase in the future, along with the success of the government's program to replace kerosene with L.P.G. started in 2007. Nevertheless, this demand for L.P.G. is projected to continue increasing by 17.4 tons in 2050.

The use of D.M.E. to substitute L.P.G. is still being reviewed by the government. This policy is expected to be implemented in 2022 by considering the price and calorific value of D.M.E. lower than L.P.G. [2]. Table 1 shows the comparison of the properties of L.P.G., propane, and butane.

D.M.E. raw feedstock can be synthesized from various sources such as natural gas, coal, biomass waste, methanol, carbon dioxide, etc. Figure 1 shows several sources of raw materials and their synthesis process routes. Coal and biomass wastes are processed through gasification into syngas [3]. Natural gas is converted into syngas through the reforming process, steam reforming, partial oxidation, and auto-thermal reforming [4], [5]. The partial oxidation reaction is more efficient than the steam reforming process due to the energy surplus. The natural gas has the $\mathrm{H} / \mathrm{C}$ ratio of 4 , whereas the $\mathrm{H}_{2} / \mathrm{CO}$ ratio of D.M.E. production is two so that there is 1 mole $\mathrm{H}_{2}$ excess when using steam reforming, with the following reaction equation:

Steam-methane reforming

$\mathrm{CH}_{4}+\mathrm{H}_{2} \mathrm{O}$ (+ heat) $\rightarrow \mathrm{CO}+3 \mathrm{H}_{2}$

Partial oxidation of methane reaction

$\mathrm{CH}_{4}+1 / 2 \mathrm{O}_{2} \rightarrow \mathrm{CO}+2 \mathrm{H}_{2}$ (+ heat)

It indicates that steam reforming is an endothermic reaction (requires heat), whereas partial oxidation is exothermic so that it can be more economical even though there is no hydrogen surplus. Then, syngas with the $\mathrm{H} / \mathrm{C}$ 
ratio of 2:1 become the raw material and are carbon dioxide can be synthesized into methanol further synthesized into D.M.E. Meanwhile,

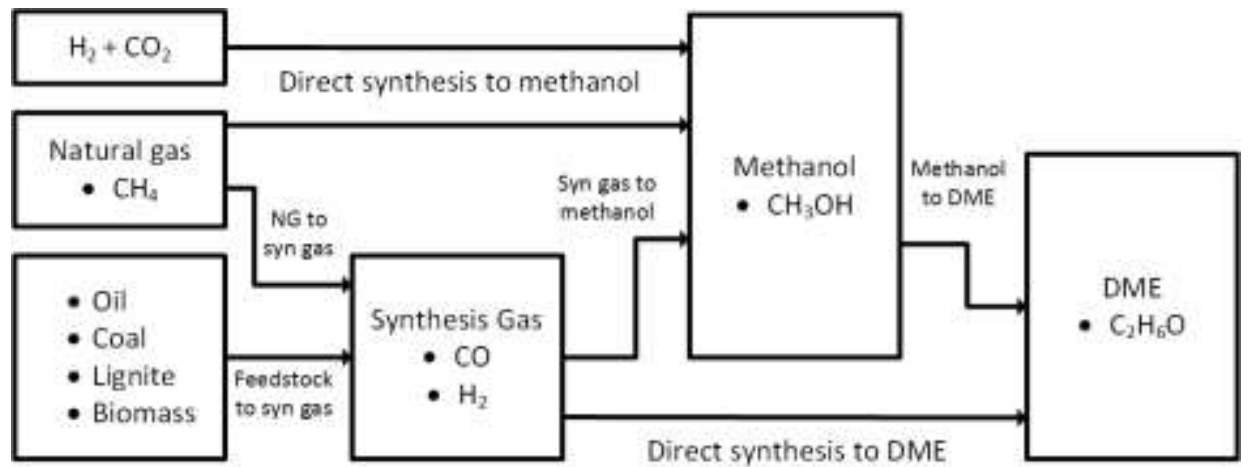

Figure 1. Several feedstock sources and synthesis process routes for D.M.E. production

Generally, D.M.E. can be produced in 2 methods, namely the direct process (one-step process) and the indirect process (two-step process). Both processes can be seen in Figure 1. The indirect process begins with the production process of methanol from syngas, followed by a dehydration reaction. In the one-stage process, syngas is directly synthesized into D.M.E. with a bi-functional catalyst [3], [9].
However, the single-stage D.M.E. synthesis process developed by companies such as Haldor-Topsoe, J.F.E., and Air Products has not been commercially viable [9]. This process is simple and uses only one reactor. However, the separation process is much more complex and expensive than the two-step process because this one-step process separates the gases [10].

Table 1. Physical properties of DME, propane, dan n-butane [3], [9], [10], [11]

\begin{tabular}{lrrr}
\hline \multicolumn{1}{c}{ Parameter } & \multicolumn{1}{c}{ D.M.E. } & \multicolumn{1}{c}{ Propane } & n-Butane \\
\hline Chemical formula & $\mathrm{CH}_{3} \mathrm{OCH}_{3}$ & $\mathrm{C}_{3} \mathrm{H}_{8}$ & $\mathrm{C}_{4} \mathrm{H}_{10}$ \\
Boiling point $\left({ }^{\circ} \mathrm{C}\right)$ & -25.1 & -42 & -0.5 \\
Freezing point $\left({ }^{\circ} \mathrm{C}\right)$ & -141.67 & -187.61 & -138.33 \\
Liquid density $\left(\mathrm{g} / \mathrm{cm}^{3}, 20^{\circ} \mathrm{C}\right)$ & 0.67 & 0.49 & 0.57 \\
Specific gravity $(\mathrm{vs}$. udara) & 1.59 & 1.52 & 2.00 \\
The heat of evaporation $(\mathrm{kcal} / \mathrm{kg})$ & 111.7 & 101.8 & 92.1 \\
Saturated vapor pressure $\left(\mathrm{atm}, 25^{\circ} \mathrm{C}\right)$ & 6.1 & 9.3 & 2.4 \\
Critical temperature $\left({ }^{\circ} \mathrm{C}\right)$ & 126.83 & 96.72 & 152 \\
Critical pressure $(\mathrm{bar})$ & 53.7 & 42.47 & 37.96 \\
Burning velocity $(\mathrm{cm} / \mathrm{s})$ & 50 & 43 & 41 \\
Ignition energy $(\mathrm{M} . \mathrm{J})$. & 45 & 30 & 76 \\
Ignition temperature $\left({ }^{\circ} \mathrm{C}\right)$ & 350 & 504 & 430 \\
Flammability limit $(\%)$ & $3.4-17$ & $2.1-9.4$ & $1.9-8.4$ \\
Cetane Number & $55-60$ & 5 & 10 \\
Net calorific value $\left(\mathrm{kcal} / \mathrm{Nm}^{3}\right)$ & 14.200 & 21.800 & 28.300 \\
Net calorific value $(\mathrm{kcal} / \mathrm{kg})$ & 6.900 & 11.100 & 10.930 \\
\hline
\end{tabular}

Based on Table 1, several parameters that make D.M.E. can be mixable with L.P.G., such as:

1. The D.M.E. boiling point is between propane and $n$-butane so that it is easy to liquefy like L.P.G.

2. The density in the liquid phase of D.M.E. does not differ much from propane and n-butane.
3. The saturated vapor pressure of D.M.E. is between propane and n-butane.

4. D.M.E. has a very high critical temperature $(400 \mathrm{~K})$ that can be liquefied at room temperature.

Besides the physical properties above, D.M.E. also has the following properties [12]: 
1. Safe for users (non-carcinogenic, nonteratogenic, non-mutagenic, and non-toxic).

2. Friendly to the environment. D.M.E. does not cause pollution in the form of soot, SOx, and NOx. Also, D.M.E. does not cause ozone damage that has a low potential to result in global warming.

3. Not corrosive to metal.

To support the government policy of the use of D.M.E. as a substitute for L.P.G. in the use of household stoves, this study aims to determine the effect of $100 \%$ D.M.E. and DME/LPG mixtures $(50 / 50,80 / 20)$ on the stability of the DME/LPG mixture. Besides, comparing the use of DME/LPG on various types of stoves and calculating their efficiency.

Nevertheless, D.M.E. can degrade and dissolve rubber/polymers that cause gas fuel leakage and become unsafe. Therefore, the impact of using D.M.E. on rubber/polymer materials was also identified for safety reasons when using it as fuel in the stove. The materials tested are rubber on the regulator, tube valve, and hose. The purpose of testing rubber/polymer on household stove accessories is to determine the extracted material in DME/LPG and the amount of DME/LPG absorbed by the polymer rubber.

\section{METHODS}

\section{Heat Loading Testing on Several Types of Stoves}

Testing for the DME/LPG mixture was carried out on a laboratory scale with a manual DME/LPG mixing system in a $3-\mathrm{kg}$ cylinder shown in Figure 2 and Figure 3.

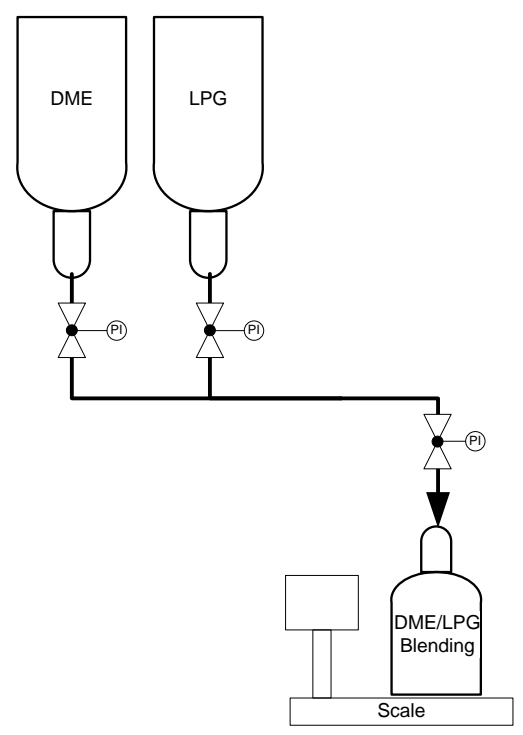

Figure 2. Laboratory scale DME/LPG mixing system flow diagram

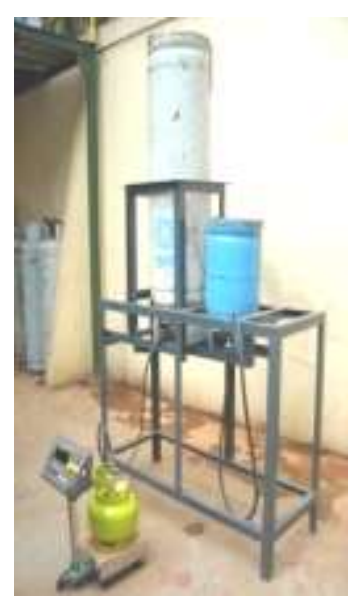

Figure 3. DME/LPG mixing system equipment

The DME/LPG mix is based on percent by weight. First, an empty-3-kg-LPG cylinder was weighed as the initial mass. Then, L.P.G. was fed into a 3-kg cylinder, followed by D.M.E. according to the desired variable weight, namely DME/LPG 0/100, 20/80, 50/50, 80/20, and 100/0 (see Table 2). The variables for heating load are $1 \mathrm{~kg}$ of water, $2 \mathrm{~kg}$ of water, and $3 \mathrm{~kg}$ of water with three repetitions. Heat loading on the water is carried out using several types of stoves with different stove designs, namely the Quantum for L.P.G. stove, the Denpoo for L.P.G. stove, the Quantum for LPG-DME stove, and the Quantum for D.M.E. stove (shown in Figure 4), hereafter referred to as the $A, B, C$ stove, and $D$.

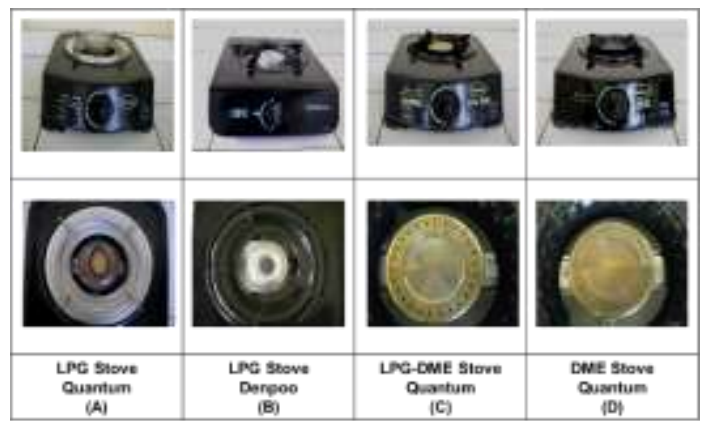

Figure 4. Several stoves were used in testing the DME/LPG mixture

Before testing, the initial mass of fuel (in a 3$\mathrm{kg}$ cylinder) and water were recorded. The water was boiled with the specified variable fuel to $100^{\circ} \mathrm{C}$, and the heating time was recorded simultaneously. After reaching the boiling temperature, the final mass of fuel (in a $3-\mathrm{kg}$ cylinder) and water were recorded to determine 
the mass reduction of fuel and water. Then, the heating value is calculated in equations 1 ) - 3).

$$
\begin{aligned}
& Q_{b}=\frac{m}{B M} R \int \frac{C p}{R} d T \\
& Q_{u}=m\left(H_{v}-H_{l}\right) \\
& Q_{a i r}=Q_{b}+Q_{u} \\
& \text { Where, }
\end{aligned}
$$

$\mathrm{Q}_{\mathrm{b}} \quad=$ Sensible heat of water

$\mathrm{Qu}_{\mathrm{u}} \quad=$ Latent heat of water

$Q_{\text {water }}=$ Required heat to boil water

$\frac{\mathrm{Cp}}{\mathrm{R}}_{\text {water }}=8.712+1.25 .10^{-3} \mathrm{~T}-0.18 .10^{-6} \mathrm{~T}^{2}$

$\mathrm{H}_{\mathrm{v}}=2676 \mathrm{~kJ} / \mathrm{kg}$

$\mathrm{H}_{\mathrm{l}} \quad=419 \mathrm{~kJ} / \mathrm{kg}$

Meanwhile, the calorific values of fuel combustion are calculated based on the mass fraction of the two mixtures with equation 4), and the efficiencies of the stove are calculated with equation 5).

$Q_{\text {.D.M.E./LPG }}=\mathrm{x}_{1} \mathrm{NCV}_{1} \times \mathrm{x}_{2} \mathrm{NCV}_{2}$

$\eta_{\text {stove }}=\frac{Q_{\text {total water }}}{Q_{\text {DME } / \text { L.P.G }}}$.

Where,

$\mathrm{X}_{1}, \mathrm{X}_{2}=$ mole fraction of each compound (D.M.E., L.P.G.)

$\mathrm{NCV}_{1}, \mathrm{NCV}_{2}=$ Net calorific value for each compound (D.M.E., L.P.G.)

$Q_{D M E / L P G}=$ Energy of fuel combustion to boil the water

Table 2. Stove types and fuel blend ratios for the experiment

\begin{tabular}{cl}
\hline \multicolumn{1}{c}{ Type of Stove } & \multicolumn{1}{c}{ Fuel } \\
\hline Stove A & LPG $100 \%$, \\
& D.M.E. $20 \%$ \\
Stove B & LPG $100 \%$, \\
& D.M.E. $20 \%$ \\
Stove C & D.M.E. $50 \%$ \\
Stove D & D.M.E. \\
& $80 \%$, DME \\
& $100 \%$, LPG \\
& 100 \\
\hline
\end{tabular}

\section{Stability of DME/LPG Mixture Testing}

Each 3-kg-LPG cylinder was filled with a mixture of DME / LPG 0/100, 20/80, 50/50, 80/20, and $100 / 0$ with the equipment in Figure 3. Then sampling is carried out for both the gas and liquid phases. The first sample was taken after mixing (0), then the next samples were taken after 1, 2, $3,4,5$, and 11 hours.

The gas and liquid samples were analyzed using Yanaco Gas Chromatography (G.C.) Flame lonization Detector (FID) type G2800. The column used was Porapak-Q stainless steel with a length of $1 \mathrm{~m}$ using $\mathrm{N}_{2}$ as the carrier gas. The column, injector, and detector temperatures were set at $140^{\circ} \mathrm{C}$ with a heating rate of $5^{\circ} \mathrm{C} / \mathrm{min}$.

\section{Rubber/Polymer Materials Testing of Household Stoves Accessories in DME/LPG Mixture}

Testing rubber/polymer samples from several parts of the stove and their accessories is by immersing the sample in the DME / LPG mixture according to the S.N.I. standard shown in Table 3.

Table 3. Standards used for rubber/polymer testing [13]

\begin{tabular}{ll}
\hline Part of the Stove & \multicolumn{1}{c}{ S.N.I. Standard } \\
\hline Tube valve & S.N.I. 06-7213-2006 \\
& S.N.I. 7369:2008 \\
Hose & S.N.I. 06-7213-2006 \\
Regulator & S.N.I. 7369:2008 \\
\hline
\end{tabular}

Some parts of the tube valve, such as plastic guide, control cap rubber, seal rubber, and rubber pad shown in Figure 5, were rubber/polymer samples tested.

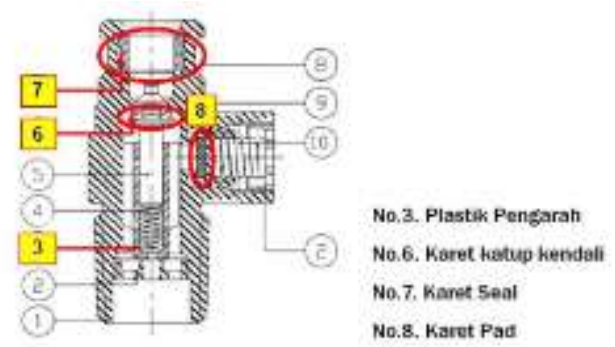

Figure 5. Tube valve part

Meanwhile, the tested gas cylinder regulator consists of several parts such as the membrane rubber, valve bearings, and the seal ring shown in Figure 6.

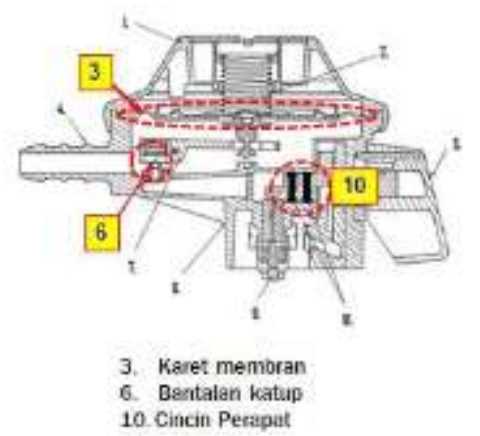

Figure 6. Gas cylinder regulator part 
Several mixtures of DME/LPG such as 100 , $80 / 20,50 / 50,30 / 70,20 / 80,100$ were prepared in each 3-kg-cylinder shown in Figure 2. Then, the cylinder containing the mixture DME/LPG is fed into an autoclave to immerse rubber/polymer materials. Figure 7 shows a flow diagram of the rubber/polymer material testing system.

First of all, sample cutting and drying were performed. The dried sample was to determine the initial mass. Then, the rubber/polymer sample was placed into an autoclave. A specific composition of DME/LPG mixture was flowed into the autoclave up to $1 \mathrm{~kg}$. After 72 hours, the sample was taken out and weighed. Then, the sample was aging for 24 hours in the open air and then weighed.

Air weighing was carried out to determine mass differences due to absorption and desorption of the sample. Then, the volume change was determined by immersing the sample into the water. The same method was applied for n-heptane as solvent according to the S.N.I. standard.

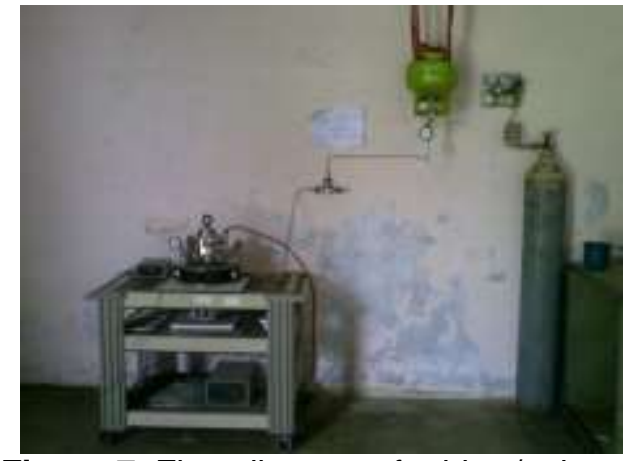

Figure 7. Flow diagram of rubber/polymer testing in the DME/LPG mixture

\section{RESULTS AND DISCUSSION}

\section{Research Results Heat Loading Testing on Several Types of Stoves}

Table 4 shows the calorific value of each DME/LPG fuel composition. The calorific value of DME/LPG mix fuel decreases because of increasing D.M.E. in the mixture. The low calorific value of D.M.E. $(6,900 \mathrm{kcal} / \mathrm{kg})$ causes a problem such as frequent fuel changes.

Table 4. Calorific Value of DME/LPG mixtures

\begin{tabular}{cc}
\hline $\begin{array}{c}\text { DME/LPG } \\
\text { composition } \\
\text { (\%weight/\%weight) }\end{array}$ & $\begin{array}{c}\text { Calorific Value } \\
\text { (kcal/kg) }\end{array}$ \\
\hline $0 / 100$ & 11,667
\end{tabular}

\begin{tabular}{ll}
$20 / 80$ & 10,615 \\
$50 / 50$ & 9,135 \\
$80 / 20$ & 7,762 \\
$100 / 0$ & 6,900 \\
\hline
\end{tabular}

Table 5 shows the efficiency values of stoves with various DME/LPG mix compositions. Stove $C$ has the best performance efficiency for the fuel composition of 50/50 because of the stove design. A good stove performance is not only affected by a larger burner cap opening but also a nozzle size [14]. One parameter on the stove design is the flammability limit for each fuel. The flammability limit of D.M.E. is greater than that of propane and butane. It means that D.M.E. needs a higher concentration in the air to lead the flame.

Table 5. The efficiency value of various types of stoves fueled by DME/LPG mixed fuel

\begin{tabular}{|c|c|c|}
\hline $\begin{array}{l}\text { DME/LPG } \\
\text { composition }\end{array}$ & Stove type & $\begin{array}{c}\text { Stove } \\
\text { efficiency } \\
(\%)\end{array}$ \\
\hline \multirow{2}{*}{$0 / 100$} & $\begin{array}{l}\text { Stove A } \\
\text { (L.P.G. } \\
\text { Stove) }\end{array}$ & 56.13 \\
\hline & $\begin{array}{l}\text { Stove D } \\
\text { (D.M.E. } \\
\text { Stove) }\end{array}$ & 51.51 \\
\hline $20 / 80$ & $\begin{array}{l}\text { Stove B } \\
\text { (L.P.G. } \\
\text { Stove) }\end{array}$ & 55.80 \\
\hline $50 / 50$ & $\begin{array}{c}\text { Stove C } \\
\text { (LPG-DME } \\
\text { Stove) }\end{array}$ & 71.27 \\
\hline $80 / 20$ & $\begin{array}{l}\text { Stove D } \\
\text { (D.M.E. } \\
\text { Stove) }\end{array}$ & 51.92 \\
\hline $100 / 0$ & $\begin{array}{l}\text { Stove D } \\
\text { (D.M.E. } \\
\text { Stove) }\end{array}$ & 62.88 \\
\hline
\end{tabular}

The color of the flame on various types of stoves fueled by L.P.G. is shown in Figure 8. The red color of the flame on stove $D$ indicates that the stove is not suitable for L.P.G. fuel. This is closely related to the chemical formula of fuel; in the L.P.G. molecular structure, there is no oxygen bond, while there is an oxygen compound bond in D.M.E. So, it is necessary to modify the design on the stove that uses D.M.E. fuel. If this DMEfueled stove is used for L.P.G., the flame will be red, indicating incomplete combustion causes the formation of soot. 


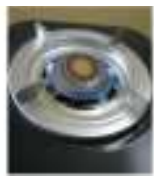

Stove A
Stove B

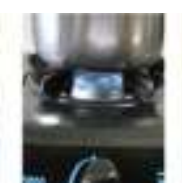

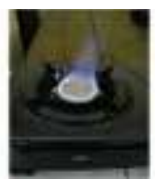

Stove C

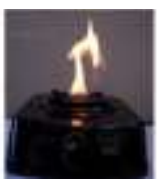

Stove D
Figure 8. The color of the flame on various types of stoves fueled by L.P.G.

The consumptions of DME/LPG fuel ( $\mathrm{gr}$ fuel $/ \mathrm{kcal}$ load) using various types of stoves were also observed in this research shown in Figure 9. The increase in fuel consumption is proportional to the D.M.E. concentration. The higher concentration of D.M.E. is in the mixture, and more fuel will be consumed [15].

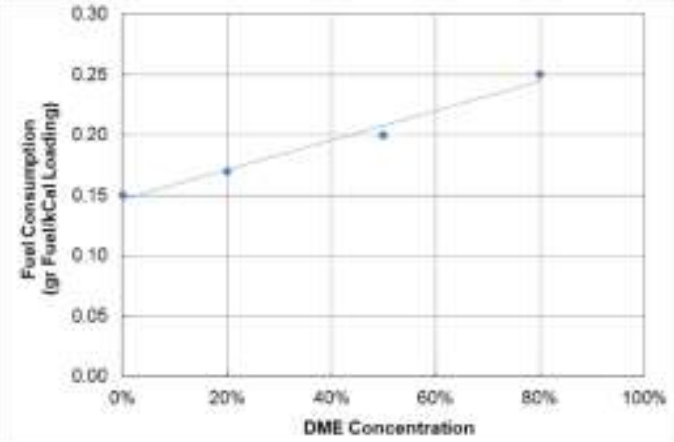

Figure 9. Fuel consumption on various D.M.E. concentration

\section{Stability of DME/LPG Mixture Testing}

The different chemical properties of L.P.G. and D.M.E. will affect the stability of the mixture. L.P.G. is non-polar while D.M.E. is slightly polar that the homogeneity of DME/LPG mixing will be immiscible because the polar and the non-polar compounds cannot dissolve each other.

The composition of the DME/LPG mixture in the gas phase is slightly different from that of the liquid phase shown in Figure 10. The concentrations of D.M.E. and propane in the DME/LPG mixture in the gas phase tend to be more than the liquid phase, while the butane concentration is higher in the liquid phase. This happens because the vapor pressure of D.M.E. (6.1 atm) and propane (9.3 atm) is greater than the vapor pressure of butane (2.4 atm).

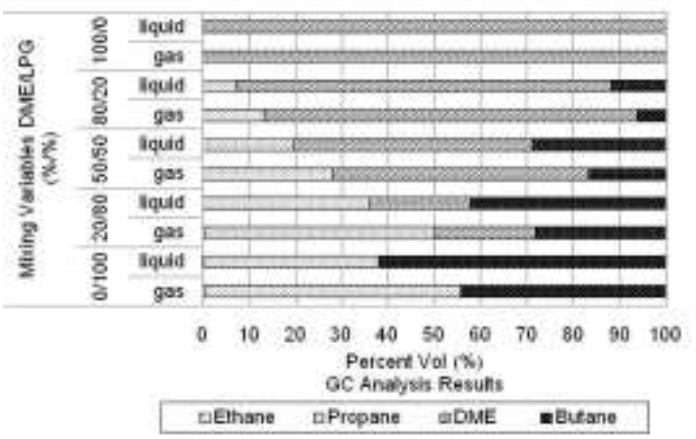

Figure 10. The composition of the gas phase and the liquid phase in the DME/LPG mixture

If the DME / LPG mixture inside the cylinder is released throughout the time, the composition of the mixture will be changed every time. Figure $\mathbf{1 1}$ shows $100 \%$ L.P.G. (containing ethane, propane, and butane) released at certain time intervals. The gas and liquid phases L.P.G. composition in the cylinder is averaged $40 \%$ propane, $60 \%$ butane, and $0.04 \%$ ethane. The concentration of butane in both gas and liquid phases increases with time, while the propane concentration in both phases becomes smaller. Ethane has the same trend as propane. The ethane concentration decreases from 0.4 to $0.03 \%$ in the gas phase and 0.11 to $0 \%$ in the liquid phase.

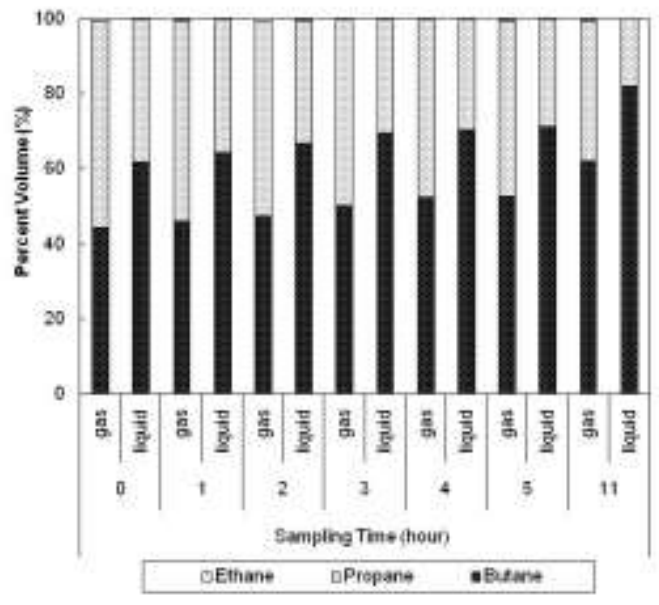

Figure 11. L.P.G. composition over time intervals 


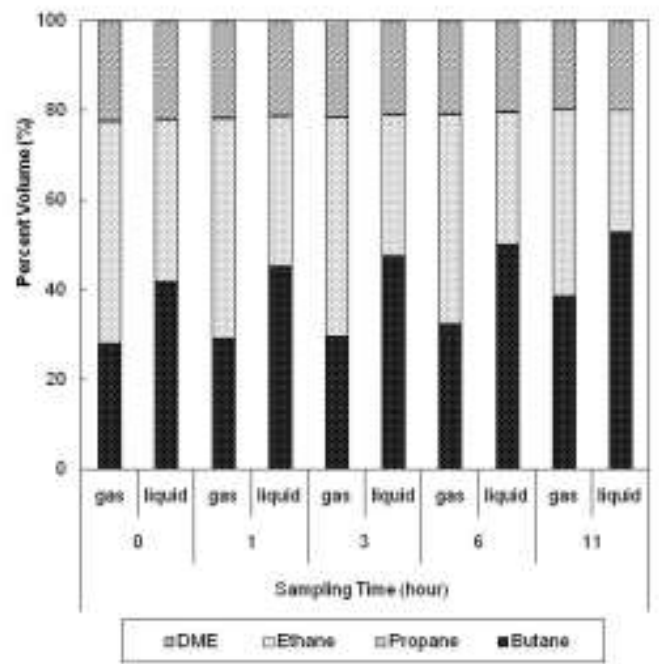

Figure 12. The composition of 20/80 DME/LPG over time intervals

The same results were obtained by the $50 / 50$ and $80 / 20$ mixtures of DME/LPG shown in Figures 13 and 14, respectively. At the $11^{\text {th }}$ hour of sampling time, the ethane composition becomes zero in all DME/LPG mixtures. The composition of the D.M.E. decreased slightly on both the 50/50 and 80/20 DME/LPG blends. The propane concentration decreases significantly around $28.5 \%$ in the gas phase and $42.1 \%$ in the liquid phase. In contrast to the butane, the concentration increased by an average of $78.6 \%$ in the gas phase and $38.4 \%$ in the liquid phase.

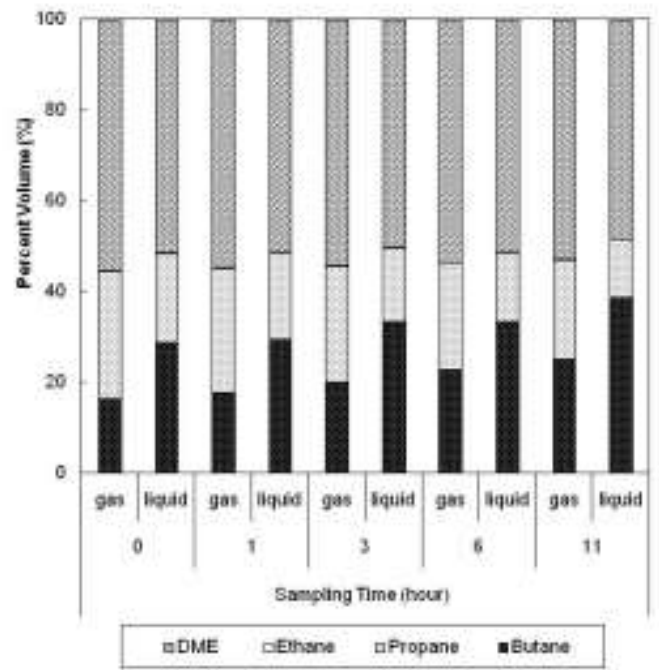

Figure 13. The composition of 50/50 DME/LPG over time intervals

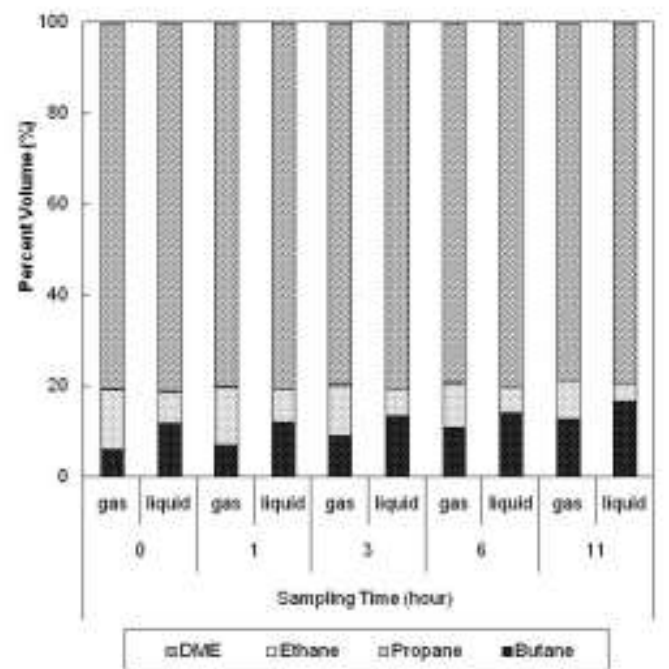

Figure 14. The composition of 80/20 DME/LPG over time intervals

If the gas in the cylinder is released for a long time, in the end, there will be only D.M.E. and butane remaining. This condition is closely related to safety factors that users need more attention to by replacing the rubber/polymer seals on the stove and its accessories regularly.

\section{Rubber/Polymer Materials Testing of Household Stoves Accessories in DME/LPG Mixture}

The immersion test for the stove material and its accessories is in accordance with the requirements for rubber/polymer-based on S.N.I. [13], which are as follows:

a. Materials on the "Regulator"

- The volume shrinks $<1 \%$ and expands $<25 \%$

- Loss of weight $<10 \%$ after 24 hours of air conditioning

b. Material on "Tube Valves"

- Change in weight and volume $<20 \%$

- Change in weight and volume $<10 \%$ after 24 hours of standing in the air

c. Materials on the "Hose"

- Absorbed liquid $<15 \%$

- Extracted $<15 \%$ after 24 hours in the air

Immersion tests for membrane rubber and hoses (a domestic membrane rubber (Quantum/U), a membrane (V), and several hoses from China (W, X, Y, Z)) carried out in nHeptane (as a substitute for $n$-hexane) are shown in Table 6. The immersion test for $U$ membrane rubber in $\mathrm{n}$-Heptane showed satisfactory results 
based on S.N.I. requirements with a percentage change in volume of $5.40 \%$ and a weight loss of 2.6\%. Meanwhile, other materials such as $\mathrm{V}$ membrane rubbers and hoses (W, X, Y, Z) do not meet the requirements. The failure distribution of regulators, valve tubes, and hoses samples from domestic in the various DME/LPG mixtures can be seen in Table 7. Based on these data, all hose materials were damaged after immersion. Based on the test indicates that the material is made of P.V.C. [16], [17], [18], [19]. The greater the D.M.E. composition in the mixture, the greater the failure rate of the material is.

Table 6. Material test results on rubber/polymer in $\mathrm{n}$-heptane

\begin{tabular}{llllll}
\hline Sample & Sample Part & $\begin{array}{c}\text { \% Weight } \\
\text { Changes }\end{array}$ & $\begin{array}{c}\text { \% Weight } \\
\text { Changes } \\
\text { (24 hours) }\end{array}$ & $\begin{array}{c}\text { \% Volume } \\
\text { Changes }\end{array}$ & $\begin{array}{c}\text { \% Volume } \\
\text { Changes } \\
\text { (24 hours) }\end{array}$ \\
\hline Regulator (U) & $\begin{array}{l}\text { Membrane } \\
\text { Rubber }\end{array}$ & -0.1951 & -10.9417 & 2.8181 & -10.5792 \\
Regulator (V) & $\begin{array}{l}\text { Membrane } \\
\text { Rubber }\end{array}$ & -0.5437 & -2.6019 & 5.3951 & -1.8891 \\
Hose & & \% absorbed & \% extracted & & \\
W & 6.8244 & 27.0101 & -10.8213 & -30.6012 \\
X & 7.9408 & 28.0641 & -7.3219 & -30.3626 \\
Y & 7.3052 & 25.5952 & -1.7827 & -29.4071 \\
Z & 2.07 & 25.9467 & -18.5906 & -32.4045 \\
\hline
\end{tabular}

Table 7. Failure distribution of domestic samples for regulators, cylinder valves, and hoses in various DME/LPG mixtures

\begin{tabular}{lcccccc}
\hline \multicolumn{1}{c}{ Materials } & \multicolumn{5}{c}{ DME/LPG Mixtures } \\
\cline { 2 - 7 } & $\mathbf{0 / 1 0 0}$ & $\mathbf{2 0 / 8 0}$ & $\mathbf{3 0 / 7 0}$ & $\mathbf{5 0 / 5 0}$ & $\mathbf{8 0 / 2 0}$ & $\mathbf{1 0 0 / 0}$ \\
\hline Regulator & & 2 & 2 & 2 & 1 & 1 \\
$\begin{array}{l}\text { Membrane Rubber (2) } \\
\text { Valve bearings (2) }\end{array}$ & & 1 & na & 1 & 1 & na \\
$\begin{array}{l}\text { Seal ring (2) } \\
\text { Cylinder valve }\end{array}$ & 2 & na & & na & 2 & 2 \\
$\begin{array}{l}\text { Plastic guides (2) } \\
\text { Rubber control valve (2) }\end{array}$ & & & & 1 & 1 & \\
$\begin{array}{l}\text { Rubber Seals (2) } \\
\text { Rubber Pads (2) }\end{array}$ & 1 & 1 & 1 & 1 & 1 & 1 \\
$\begin{array}{l}\text { Hose } \\
\text { Inner lining (2) }\end{array}$ & & & & & & 1 \\
$\quad \begin{array}{l}\text { Total } \\
\text { \% FAlLURE }\end{array}$ & 3 & 4 & 4 & 6 & 7 & 1 \\
\hline
\end{tabular}

Remarks:

- Each material was tested under two conditions (variables): the changes after 72 hours of immersion and after being left for 24 hours in the open air.

- $\quad$ na $=$ not available

Testing on the Quantum membrane rubber regulator in $\mathrm{n}$-Heptane showed that the sample part was not damaged. The testing of regulator material with L.P.G. and D.M.E. mixture as a solvent directly turned out to be more severe than testing with S.N.I. standard solvents. Tests show that the domestic regulator material and hoses are better than $(\mathrm{V}, \mathrm{W}, \mathrm{X}, \mathrm{Y}, \mathrm{Z})$ products on the use of $30 \%$ D.M.E. mixture. Thus, it can be concluded that the existing products of L.P.G. stove accessories in the domestic market are safe to use for the DME / LPG mixtures up to $30 / 70$.

\section{CONCLUSION}

The most efficient and economical production process of D.M.E. is fed from natural gas because the $\mathrm{H} / \mathrm{C}$ ratio of D.M.E. is 3 , and the $\mathrm{H} / \mathrm{C}$ ratio of natural gas is 4 . The highest efficiency of the stove with blending DME/LPG was obtained 
by stove C (LPG-DME stove) with the blending DME/LPG ratio of $50 / 50$ achieved $71.29 \%$. This result shows the stove design has an enormous effect on efficiency. The increasing D.M.E. ratio in the blending fuel can raise fuel consumption. The material testing shows that the use of a DME/LPG mixture between 20/80 - 30/70 does not require the replacement of the materials but only slightly requires modification on the stove. The optimum usage of the DME/LPG mixture is a $20 / 80$ mixture. The use of a DME/LPG mixture above $20 / 80$ is no longer able to keep up with both the efficiency and the calorific value. If the concentration of D.M.E. is added to the fuel mixture, it is necessary to replace the seal for safety and security reasons because of the rubbery nature of the D.M.E.

\section{AUTHOR INFORMATION}

\section{Corresponding Authors}

E-mail: galuh.wirama@bppt.go.id.

Phone: +62 8563676167

E-mail: unggul.priyanto@bppt.go.id.

\section{Author Contributions}

First Author and Second Author have contributed equally to this work.

\section{ACKNOWLEDGMENTS}

This research had been financially supported by P.T. Pertamina. Technical equipment and experimental activities were supported by the P.T.S.E.I.K. team. All support is gratefully acknowledged. Also, the assistance of durability material testing provided by B.T.P. (Centre of Polymer Technology) was greatly appreciated.

\section{REFERENCES}

[1] DEN, "Outlook Energi Indonesia 2019", 2019, ISSN 25273000.

[2] BPPT, "Outlook Energi Indonesia 2019", Jakarta, BPPT, 2019, ISBN 978-602-132810-1.

[3] Ali Bakhtyari, Mohammad R. Rahimpour, "Chapter 10 - Methanol to Dimethyl Ether", Editor(s): Angelo Basile, Francesco Dalena, "Methanol", Elsevier, 2018, Pages 281-311, ISBN 9780444639035 , https://doi.org/10.1016/B978-0-444-639035.00010-8.
[4] Makarand R G, "The Direct Dimethyl Ether (D.M.E.) Synthesis Process from Syngas: Current Status and Future Prospects I. Process Feasibility and Chemical Synergy in LPDME $^{\text {tm }}$ Process", Progress Petrochem Sci .2 (4), Pages 547-554, 2018 August 16, DOI: 10.31031/PPS.2018.02.000542

[5] Uddin, Mosleh \& Simson, Amanda \& Wright, Mark, "Techno-economic and greenhouse gas emission analysis of dimethyl ether production via the bi-reforming pathway for transportation fuel", Energy 211, 2020, 119031.

[6] Catizzone E, Bonura G, Migliori M, Frusteri $\mathrm{F}$, Giordano $\mathrm{G}$, " $\mathrm{CO}_{2}$ Recycling to Dimethyl Ether: State-of-the-Art and Perspectives", Molecules, 2017 Dec 24;23(1):31.

[7] Hankin A., N. Shah, "Process exploration and assessment for the production of methanol and dimethyl ether from carbon dioxide and water", Sustainable Energy Fuels, 2017, 1, 1541 -1556, DOI: 10.1039/c7se00206h

[8] Leonzio, G., "State of art and perspectives about the production of methanol, dimethyl ether and syngas by carbon dioxide hydrogenation", Journal of $\mathrm{CO}_{2}$ Utilization, 27, 326-354. 2018, doi:10.1016/j.jcou.2018.08.005.

[9] Japan D.M.E. Forum (J.D.F.), "D.M.E. Handbook", Ohmsha, Ltd., 2007, ISBN 9784-9903839-0-9 C3050.

[10] I.A. Kurzina, S.I. Reshetnikov, N.I. Karakchieva, L.N. Kurina, "Direct synthesis of dimethyl ether from synthesis gas: Experimental study and mathematical modeling", Chemical Engineering Journal, Volume 329, 2017, Pages 135-141, ISSN 1385-8947, https://doi.org/10.1016/j.cej.2017.04.132.

[11] C.P.C., "International Liquefied Gas Propellant Handbook".

[12] Singh A. P., R. A. Agarwal, A. K. Agarwal, A. Dhar, M. K.Shukla, "Prospects of Alternative Transportation Fuels", Springer Nature Singapore Pte Ltd., 2018, https://doi.org/10.1007/978-981-10-7518-6

[13] Badan Standarisasi Nasional, "SNI 8660:2018 Kompor gas LPG dan LNG/NG Tekanan Rendah untuk Rumah Tangga”, Badan Standardisasi Nasional, Jakarta. 2018.

[14] D. Mandaris, P. Bakti, H. Tjahjono, "Karakteristik Kompor Gas Berbahan Bakar DME (Dimethyl Ether) Berbasis SNI 
7368:2011", Jurnal Standardisasi 16(1):7, March 2014, DOI: 10.31153/js.v16i1.79.

[15] Anggarani, Riesta \& Dhiputra, Made \& Setyo Wibowo, Cahyo \& Rulianto, Dimitri, "Technology Development on The Use of Dimethyl Ether as Fuel: Review", 40, 2017, 10.29017/SCOG.51.1.41-51.

[16] Tuti Indah Sari, Asep Handaya Saputra, Dadi R. Maspanger and Setijo Bismo, "Modification of Natural Rubber as a Resistant Material to Dimethyl Ether", Journal of Applied Sciences, 17: 53-60, 2017.
[17] Kass, Michael D., and Charles Daw. "Compatibility of Dimethyl Ether (D.M.E.) and Diesel Blends with Fuel System Polymers: A Hansen Solubility Analysis Approach." S.A.E. International Journal of Fuels and Lubricants, vol. 9, no. 1, 2016, pp. 71-79.

JSTOR,www.jstor.org/stable/26273452. Accessed 18 Aug. 2021.

[18] Wu, N., Zhang, W. \& Huang, Z, "Impact of dimethyl ether on engine seal materials", Front. Energy Power Eng. China 2, 279284, 2008, https://doi.org/10.1007/s11708008-0042-1

[19] https://www.marcorubber.com/o-ringchemical-compatibility-chart.htm (Accessed on May 2019). 